\title{
A Feminist Analysis of Alexandra in O Pioneers*
}

\author{
LIU Xi, WU Yi \\ Changchun University, Changchun, China
}

\begin{abstract}
Willa Cather was the first woman frontier writer in American literary history who devoted herself to the portrayal of frontier life of pioneers in the Middle West America. She has successfully created a series of moving women images. Most of Cather's female images are strong-minded and independent, attempting to take the fate into their own hands. In a sense, she can be regarded as a precursor of modern feminism. O Pioneers is the first mature book of Willa Cather, with the heroic protagonist, Alexandra, the representative of such women characters. With the application of the feminist literary approach, the thesis makes a detailed analysis of the heroine Alexandra in an attempt to illustrate and prove Cather's feminist thinking tendency. The present paper aims to analyze the feminist thoughts of Alexandra from the perspectives of her Revolt against "Woman Myth”, her struggle against patriarchal society, and her longing for a real equality between men and women.
\end{abstract}

Keywords: revolt, feminism, struggle, equality, patriarchal society

\section{Introduction}

Willa Cather (1873-1947) was the first female writer in America literary history who depicted the frontier life of pioneers in the Middle West America. She was best known for such novels as O Pioneers and My Antonia. She used her creative theme and artistic style full of unique characteristics to open a paradise with her unique charm in the history of American literature.

In her literary life, she created a series of memorable women images with pioneering spirit and feminist thoughts, including frontier women, cosmopolitan artists, and so on. Those women are Alexandra Bergson in $O$ Pioneers, Antonia in My Antonia, who were able to transcend traditional expectations of women or smash the bonds of male perceptions. In contrast, with the obvious strength of her women characters, most of Willa Cather's male characters were rather weak and ineffectual, such as Carl in O Pioneers, Jim Burden in My Antonia.

In $O$ Pioneers, Willa Cather depicted two stories. One was Alexandra's struggle against nature and even male society in the process of pioneering and her final triumph over the land. The other was the tragic love story between Marie and Emil. Alexandra Bergson, a Swedish immigrant, was the heroic protagonist of this novel. She succeeded in establishing her female identity and achieved a sense of female self-fulfillment by transforming the wild land and struggling for her equal rights with men. Willa Cather's creation of this heroic Alexandra not only foreshadowed her inclination to create more female images with feminist thoughts in her later works, but also

\footnotetext{
* Acknowledgements: This paper is part of the result of the research programs the authors have participated "The Study of Counter-Elite Essentiality in American Post-modernism Novels" (2013) No. 265.

LIU Xi, lecturer, M.A., School of Foreign Languages, Changchun University.

WU Yi, associate professor, M.A., School of Foreign Languages, Changchun University.
} 
served as a good example to exemplify her feminist ideas and attitude.

This paper focuses on the feminist thoughts and pioneering spirit of the great image of the heroine-Alexandra, who was independent, brave, and optimistic. Getting strength and courage from her such spirit, Alexandra would never be defeated by either men or nature.

\section{Her Pioneering Spirit Against Men and Nature}

The famous king of Macedon (Alexander the Great) led his army to conquer large areas of Europe and created the splendid empire. Just like her male ancestor, Alexandra, the heroic female protagonist in O Pioneers also established her own "empire" on the colossal wilderness of American West. She turned the wild land into the prosperous countryside and became one of the most prosperous farmers on the Divide after 16 years' struggle. Both of them were conquerors and creators, while their feats were totally different. For that, Alexander was just a female whose desire for achievements was not acknowledged.

However, "Cather won't be bounded by such gender-discrimination tradition and prejudiced myth and her Alexandra is a challenge to this 'Woman Myth' - an actual prejudice against women" (Woodress, 1990, p. 39). Her Alexandra seems to be more a woman of head than one of heart. With the great intelligence, reason, open-mindedness, and strength of will, she not only gains a spiritual and eventual success over the frontier, but also transcends all the male characters around her.

The story started from a gloomy town named Hanover, which was so small that there were only "a cluster of low drab building huddled on the gray prairie, under a gray sky" (Ryan, 1998, p. 21) with snowflakes curling and eddying about. The fact was the land itself, which seemed to overwhelm the little beginnings of human society that struggled in its "somber wastes".

With so many calamities like crop failures and diseases, Bergson was so depressed that he died at an early age of 46. Bergson had to entrust his family's future and the task of taming the land to Alexandra because "the boys were not as half intelligent as their sister" (Cather, 1987, p. 76).

Alexandra was the first child of Bergson's four children together with three boys, Oscar, Lou, and Emil. She was a tall, strong girl, walking rapidly as if she knew exactly where she was going and what she was going to do next. She wore a man's long coat and had a serious, thoughtful face and "her clear deep eyes were fixed intently on the distance..." (Cather, 1987, p. 52). Through the description of her dress and her appearance, Willa Cather presented us with an intelligent, powerful, and independent woman image who was totally different from the stereotyped weak women images. Alexandra was bound to achieve her self-fulfillment in the taming of the wild land and bringing modern civilization to it with her unusual pioneering spirit.

Willa Cather believed that "a pioneer should have imagination, should be able to enjoy the idea of things more than the things themselves" (Cather, 1987, p. 69) and Alexandra was such an image of a typical pioneer.

The task of taming the land could never be accomplished because pioneering in the wilderness demanded flexible mind and dauntless spirit. During the tough process of pioneering, if the pioneers were afraid of making mistakes and making changes, they would never go ahead. Unfortunately, Lou, Oscar, and their neighbors were such people because they refused to accept new ideas and reforms, sticking to the old ways.

In contrast with her brothers and neighbors, Alexandra stood out as a pioneer. In her teens, "Alexandra could make more money than a hired man by raising chickens and cows" (Cather, 1987, p. 135). She knew where her 
advantages lied in, compared with the men. She asked Ivar for advice on the caring of her big bunch of hogs. The old man suggested reforms in the traditional way of raising hogs, which displeased Oscar and Lou. But Alexandra followed his wise suggestion and finally succeeded. What is more, she also learned from one young farmer who had been away at school. It is Alexandra who put up the first silo on the Divide; it is Alexandra who said the land was ready for wheat and had to raise three big wheat crops before others quit putting all their land in corn. Alexandra's open-mindedness enabled her to adapt to the circumstances easily and embrace new ideas warm-heartedly. Therefore, she led her family and community to get through the most difficult times on the prairie.

The essential factors to Alexandra's success under the terrible circumstances include her adventurous spirit to experiment, her willingness to learn from others, and her strong will, passion, and desire. Finally Alexandra brought prosperity to her family and her community, and planted civilization to the wilderness. After 16 years, the once bleak Nebraska prairie took great changes. The prairie was now "a place of milk and honey" (Cather, 1987, p. 91) as Carl exclaimed. Willa Cather presented Alexandra as a woman possessing creativity and productivity by which Alexandra found herself with pioneering spirit.

\section{Her Revolt Against Patriarchal Society}

When Alexandra's brothers proposed to leave Divide for some habitable place, their mother was extremely exhausted and frightened. Understanding and showing great sympathy for her mother's pains, Alexandra reassures her "You don't have to go if you don't want to. A third of the land belongs to you by American law, and we can't sell without your consent" (CAO, 1995, p. 96). Ivar was a strange man. He would not wear shoes, nor had his hair cut and he also had visions while the society in which he lived in was so conservative that it would not tolerate such differences. They have built the asylum for people who are different. Under such circumstances, Alexandra spared no efforts to save poor Ivar from the possible prosecutions. Finally because she fiercely opposed his proposal, Lou was forced to drop the topic of sending Ivar to an asylum. Law served for wealth. Once women were independent economically, they had the ability and strength to protect their interests and others'.

Alexandra wanted to marry Carl regardless of his genteel poverty because Carl could understand and appreciate her. She believed that her marriage was her own business concerning nobody except them. However, her brothers strongly opposed this marriage. They pretended to mean well, warning Alexandra that Carl was chasing after her money. But what Lou and Oscar really concerned was Alexandra's property. They sought their interests impudently, even at the cost of destroying the harmonious relationship between sisters and brothers.

Alexandra penetrated their intention at the first glance. Provoked by her brothers' deceptive remarks, Alexandra realized that they valued money more than her happiness. Alexandra refuted that it was her own business whether or when to get married or not, and that she had built up the prosperity herself and it had nothing to do with her brothers. Although she was a woman, she enjoyed the right to deal with it in the way she liked.

In $O$ Pioneers, Alexandra could be regarded as an emancipated woman to some degree because she had obtained her economic independence by her work. Her economic independence enabled her to have a final say in her family affairs. It enabled her to protect her mother and Crazy Ivar. It enabled her to take an intransigent attitude in her marriage problem. In short, woman's economic independence made her voice heard by the world and forces man to take her seriously. 
In the novel, although Alexandra became economically independent and attained considerable freedom to do things according to her will, she still lived in a male-centered society in which almost everything belonged to men, including property, power, even women, and the whole world. In this sense, Willa Cather presented us with an inspiring woman image who dared to challenge and rebel against male's authority. As "Alexander", her name implied, Alexandra would not be influenced or controlled by such "little men". Woman was not the object or "the other"; woman could be a subject, a self who had her autonomy, her own mind and consciousness to decide her own destiny and choose her own way of living. But in the male culture, Alexandra had to pay a higher price for her boldness to take the fate into her own hands.

Success can bring man wealth, fame, love, and power, almost whatever he desires, whereas it brings women loneliness and a sense of resignation. Her independence, success, and power must have kept many men away since these qualities are in direct opposition to the gender-related roles. This is the great sadness of a successful woman like Alexandra. Feeling puzzled, helpless, and tired, Alexandra questioned sadly “I wonder why I have been permitted to prosper, if it is only to take my friends away from me" (Cather, 1987, p. 79). From the rebellious feminist thoughts of Alexandra, we can grasp a gleam of hope for women at that time to come to form an independent consciousness and it is a long way for women worldwide to find themselves in a patriarchal society.

\section{Her Longing for Equality With Men}

Alexandra had to get through the long and bitter winter alone for Carl left for fortune seeking and Emil went to Mexico in an attempt to escape his fruitless love. No matter for what reasons, they were welcomed to the outside world where they were related to machines, products, and one another in impersonal, rational terms. For men, there were no boundary, no barrier between society and home. If they liked, they could enter the public world to make ahead, "deal in financial calculations, compete in acquiring wealth and command bureaucratic social organization" (Cather, 1987, p. 87). Furthermore, if they wanted, they could come back home for comfort and refreshing when they got tired. He could make himself be whatever he wanted to be; he could go wherever he planed to go, and did almost whatever he wanted to do. As a result of this policy of exclusion, women were confined to the domestic sphere and the true potential of many women went unfulfilled. They were confined to such household duties always assigned to women in the sexual division of labor, such as cooking, washing, caring for children, and gardening. The space for women was so narrow that it nearly smothered them to death. Not surprisingly, Alexandra felt that:

The years seemed to stretch before the land, spring, summer, autumn, winter, spring, always the same patient fields. The patient little trees, the patient lives, always the same yearning, the same pulling at the chain-until the instinct to love had born itself and bled and weakened for the last time. Until the chain secured a dead woman, who might be cautiously released. (Cather, 1987, p. 144)

Deprived of the opportunities and freedom to enter the outside world, women could neither share with men the colorful life nor participate in the keen competition on the battlefields of life. Furthermore, they would not have many chances to embrace new ideas. Alexandra was somewhat tired of the dull life on the farms. Being intelligent and ambitious, Alexandra was an extraordinary woman who embraced new ideas and new things full of passion, imagination, and adventurous spirit. For her, life is to try, to experiment, to pursue, to adventure, to 
transcend. Alexandra yearned for the wide world to express herself and fervently hoped that she could enjoy the freedom that men enjoyed, the freedom, not just to create, but to be, to think, and to feel. Alexandra was still longing for the outside dominated by men.

Alexandra had equated her purpose and survival with the large world. As women, they were living in a house with a glass window through which they could peep at the busy and interesting life lived by men, but they were denied the entrance to participate in and enjoy it. Unfortunately, as a member of this disadvantaged group, Alexandra was forced to find another way to express her determination and her dream to grapple with the world. She projected her unrealized dream on Emil and pinned much hope on him, expecting that he could deal with the large world as her substitute. She brought Emil up like a mother and sent him to college in spite of Lou and Oscar's grudges. She treated Emil so well that it caused jealousy of Lou and Oscar.

Emil's education and opportunities satisfied Alexandra's need for larger world. And she had confidence in Emil as she did in land. Emil was a way for her to transcend herself. She once had so much confidence in Emil that he would seek a new life in the outside instead of on the land, but he disappointed her so much by indulging in his secret and illicit love for Marie, which cost his dear life. Just like a bolt from the blue, Emil's death smashed Alexandra's hope and dream into pieces relentlessly. Alexandra began to learn that no man could fulfill her dream and she should share the equal rights as men someday so as to achieve her goals by herself.

\section{Conclusion}

Through her writings, Cather also gave us a personal chronicle of artistic development: Every artist makes himself born. Now she is regarded as one of the best writers during the first half of 20th century. For Alexandra in O Pioneers, she not only gained indigence, autonomy, enjoying a sense of dignity, but also became one with the soul of nature in spirit. In the process of creating Alexandra, who was a female character imbued with consciousness and power instead of an object of male desire and yearning, Willa Cather intended to convey the below-mentioned ideas about women. Secondly, women should seek her identity in something complete and great rather than love and marriage. Cather's success and Alexandra's achievements on land demonstrated that women could never limit their imagination only to love and marriage. Thirdly, it would be so significant for a woman to obtain the economic and spiritual independence in her pursuit for self-identity. Willa Cather's conceptions about pioneer spirit and women's liberation have great significance to modern women.

\section{References}

CAO, J. H. (1995). The search for female identity: Willa Cather's female characters. Beijing: PLA Press.

Cather, W. (1987). O pioneers. Boston: Houghton Mifflin Company.

Eagleton, M. (1991). Feminist literary criticism. New York: Longman Press.

Gui, Y. Q. (1985). Selected reading in English and American literature. Beijing: Translation Company Press.

Lewis, E. (1953). Willa Cather's living. New York: Knopt Press.

Michael, P. (1996). A dictionary of cultural and critical theory. Oxford: Blackwell Publishers Ltd..

Moynihan, R. (1990). So much to be done: Women settlers on the mining and ranching frantier. Lincon: University of Nebraska Press.

Ryan, M. (1998). Womanhood in America: From colonial time to the present. New York: F.Watts Press.

William, C. (1973). The world and the parish: Willa Cather's articles and reviews 1893-1902 (Vol. 2). Lincon: University of Nebraska Press.

Woodress, J. (1990). Willa Cather: Her life and art. New York: Pegasus Press. 